\title{
Autocrine Growth Regulation of CD30 Ligand in CD30-Expressing Reed-Sternberg Cells: Distinction Between Hodgkin's Disease and Anaplastic Large Cell Lymphoma
}

\author{
Pei-Ling Hsu and Su-Ming Hsu \\ Department of Pathology, University of Arkansas for Medical Sciences, Little Rock, AR (PLH), and Departments of \\ Pathology and Immunology (SMH), National Taiwan University Hospital, National Taiwan University College of \\ Medicine, Taipei, Taiwan
}

\begin{abstract}
SUMMARY: Persistent expression of high levels of CD30 in Hodgkin's Reed-Sternberg (H-RS) cells and anaplastic large-cell lymphoma (ALCL) cells, but not in most T- or B-cell lymphomas, suggests the presence of an underlying mechanism leading to the abnormality and possible involvement of CD30 in the growth and survival of these two unique types of tumors. In this study, we examined the effect of CD30 ligand (CD3OL) on CD30-positive H-RS and ALCL cells in long-term cultures or in primary cultures. CD30L induced various degrees of proliferation in three long-term cultured H-RS cell lines (L428, HDLM-2, and KM-H2) as well as in primary cultures of $\mathrm{H}$-RS cells obtained directly from patients with Hodgkin's disease. In contrast, significant inhibition was observed in one of the ALCL cell lines (SU-DHL-1), but no growth inhibition or promotion in responding to exogenous CD30L was detected in three others (PB-1, JB-6, and McG-2), nor in primary cultures of ALCL cells. Expression of CD30L was determined by polymerase chain reaction in long-term cultured cells and by an immunohistochemical method in $\mathrm{H}-\mathrm{RS}$ or ALCL cells de novo in tissue sections. None of the H-RS and ALCL cell lines was positive for CD30L. In tissue sections, we noticed that ALCL cells were generally CD30L-negative. In contrast, the anti-CD30L antibody reacted with a majority of $\mathrm{H}-\mathrm{RS}$ cells with diffuse cytoplasmic staining. Most $\mathrm{H}$-RS cells were CD30-positive, indicating co-expression of CD30 and CD30L in the majority of lymphoma cells. The persistent high levels of CD30 and CD30L expression in $\mathrm{H}$-RS cells suggest that the autocrine CD30L-CD30 cytokine-receptor loop, in addition to having the paracrine activity previously thought to exist, could play important roles in the proliferation of $\mathrm{H}-\mathrm{RS}$ cells. In contrast, the CD30L-mediated cytotoxicity may participate in the regression or slow progression of ALCL during the early phase of the disease in selected patients. However, when the disease progresses, the ALCL cells are likely to become resistant to exogenous CD30L. (Lab Invest 2000, 80:1111-1119).
\end{abstract}

$I$ $\mathrm{n}$ addition to its presence in Hodgkin's ReedSternberg (H-RS) cells, CD30 is present in a variety of tumors or activated cells, such as (1) anaplastic large-cell lymphoma (ALCL), (2) rare cases of Lennert's lymphoma, (3) some virally transformed B or T cells or some EBV- or HTLV-1-positive lymphoma cells, (4) a cell line derived from $\mathrm{Ph}^{1}$-positive chronic myelogenous leukemia patients in blast crisis (ie, K562 cells), and (5) some B and T cells activated in vitro by mitogens or cytokines (reviewed in Hsu and Hsu, 1994). Comparison of the CD30 cDNA with known sequences indicates that the extracellular domain of CD30 is related to the members of the tumor necrosis factor receptor (TNFR) superfamily, which includes TNFR-1, TNFR-2, low-affinity nerve growth factor re-

Received April 6, 2000.

This work was supported by NSC (Taiwan) grant GT-EX89S704L and NHRI (Taiwan) grant 89-2314-B-002-089.

Address reprint requests to: Dr. S.-M. Hsu, Department of Pathology, National Taiwan University College of Medicine, 7 Chun-Shun S Road, Taipei, Taiwan 10016. Fax: 886022394 7927; E-mail: smbsu@ha.mc.ntu.edu.tw ceptor (NGFR), CD27, CD40, and CD95 (Fas/APO-1) (Dürkop et al, 1992; Smith et al, 1994).

The fact that CD30 is expressed by both tumor cells and certain activated normal lymphoreticular cells implies that it has a general cell-growth or activation role. However, persistent expression of high levels of CD30 in H-RS cells and ALCL cells, but not in most Tor B-cell lymphomas, further suggests the presence of an underlying mechanism leading to the abnormality and possible involvement of CD30 in the growth and survival of these two unique types of tumors. The latter hypothesis has received strong support from the discovery of a natural ligand for CD30 (CD30L) (Smith et al, 1993).

The reported CD30L is a 239-amino-acid type II membrane protein. It has significant structural similarity to TNF- $\alpha$, TNF- $\beta$, CD40 ligand (CD40L), and Fas ligand (FasL) (Smith et al, 1993). Transcription products of the $C D 30 \mathrm{~L}$ gene can be detected in B cells, activated $T$ cells, macrophages, granulocytes, eosinophils, and some HTLV-1-positive T-cell lines, but are absent in a number of long-term cultured ALCL and H-RS cells tested (Gattei et al, 1997; Gruss et al, 1994a, 1994b; Gruss and Herrmann, 1996; Nicod and 
Isler, 1997; Pinto et al, 1996; Shanebeck et al, 1995; Wiley et al, 1996; Younes et al, 1996). The recombinant membrane form of CD30L has been shown to exhibit classic pleiotropic cytokine activity. It enhances the proliferation of an H-RS cell line (HDLM-2), yet is cytotoxic to an ALCL cell line, Karpas 299 (Gruss et al, 1994c). The function of CD30L on H-RS cells or ALCL cells in vivo has yet to be determined.

In this study, we examined the effect of CD30L on CD30-positive H-RS and ALCL cells in long-term cultures or, for the first time, in primary cultures. In $\mathrm{H}-\mathrm{RS}$ cells, increased proliferation was noted upon treatment with exogenous CD30L. For ALCL cells, significant inhibition was observed in a long-term cell line (SU-DHL-1), but no growth inhibition or promotion in responding to exogenous CD30L was detected in three others or in primary cultures. We further examined the expression of CD30L in 21 patients with Hodgkin's disease (HD) and 16 patients with ALCL. We noted a persistent high level of CD30 and CD30L co-expression in $\mathrm{H}-\mathrm{RS}$ cells, clearly pointing to an important autocrine as well as paracrine (or juxtacrine) loop that may play a fundamental role in the pathogenesis of HD. In contrast to frequent expression of CD30L in $\mathrm{H}-\mathrm{RS}$ cells, we showed an absence of CD30L in most ALCL cells, indicating a lack of autocrine regulatory activity of CD30L-CD30 in these cells. Escape from paracrine inhibition by CD30L may play an important role in the progression of ALCL.

\section{Results}

\section{Production of CD30L-COS-7 and CD30L-293T Cells}

We have cloned the full-length coding region of $C D 30 L$ into the pBK-CMV vector in frame with the lacZ gene for proper expression in both mammalian cells and prokaryotic cells. In this study, we used the pBKCMVCD30L plasmid to introduce CD30L into COS-7 cells. The polycationic liposome reagent LipofectAMINE ä (Gibco/BRL, New York) was used as transfection reagent, as described by the manufacturer (Gibco). The plasmid for transfection efficiency control was pCMV- $\beta$ gal, which expressed $\beta$-galactosidase and allowed transfected cells to be stained blue by $\beta$-gal. The transfection efficiency was approximately $30-40 \%$.

In addition, we used the full-length coding region of $C D 30 L$ as a template and inserted into the pEGFP-N1 expression vector (CLONTECH, Palo Alto, California). This human CD30L/GFP expression vector was then transfected into 293T cells using the lipofectamine reagent ( $3 \mu \mathrm{g}$ of DNA/3 $\times 10^{5}$ cells). Forty-eight hours after transfection, the cells were analyzed by fluorescence microscopy and harvested and prepared for studies. The transfection efficiency was approximately 70-80\% (Fig. 1, A and B).

\section{Effect of CD3OL on H-RS Cells in Short-term Culture and in Primary Culture}

$\mathrm{CD} 3 \mathrm{~L}^{+}$COS-7 cells induced various degrees of proliferation in the three $\mathrm{H}-\mathrm{RS}$ cell lines. Maximal proliferation could be observed by $30 \%, 82 \%$, and $86 \%$ increases in thymidine uptake in L428, HDLM-2, and $\mathrm{KM}-\mathrm{H} 2$ cells, respectively (Fig. 2, A-C). Vectortransformed COS-7 cells had no effect on the proliferation of cultured $\mathrm{H}-\mathrm{RS}$ cells. The results were similar to that obtained with $\mathrm{CD} 30 \mathrm{~L}^{+} 293 \mathrm{~T}$ cells. Increased proliferation in $L 428$ cells could be demonstrated by a $60 \%$ increase in ODs using the MTT/PMS assay. Untransfected 293T cells and vector-transfected 293T cells had no effects on the proliferation of cultured $\mathrm{H}-\mathrm{RS}$ cells (Fig. 1C). Anti-CD30 (HeFi-1, functions as CD30L) treatment, but not Ber-H2 monoclonal antibody treatment, yielded a similar result. The numbers of cells with BUDR uptake were about the same in both control and CD30L-treated cultures.

Three cases of HD were selected on the basis of the presence of numerous $\mathrm{H}-\mathrm{RS}$ cells $(\cong 15 \%)$ in the tissues. Both un-enriched and H-RS-cell-enriched specimens were available. CD30L induced cell proliferation with an increase in thymidine uptake by 25$45 \%$ in un-enriched specimens (containing $80 \%$ contaminating lymphocytes and histiocytes) and by 52 $100 \%$ in enriched specimens (containing less than 5\% contaminating cells) (Fig. 2, D-F), indicating that the proliferation was derived primarily from $\mathrm{H}-\mathrm{RS}$ cells and not from contaminating cells.

\section{Effects of CD3OL on ALCL Cells}

We showed that the $\mathrm{CD} 0 \mathrm{~L}^{+} \mathrm{COS}-7$ cells, $\mathrm{CD}^{+} \mathrm{L}^{+}$ 293T cells, or anti-CD30 ( $\mathrm{HeFi}-1)$ inhibited the proliferation of SU-DHL-1 cells (Fig. 2G), but failed to provoke any significant changes in three other ALCL cell lines (JB-6, MeG-2, PB-1) as well as in two primary
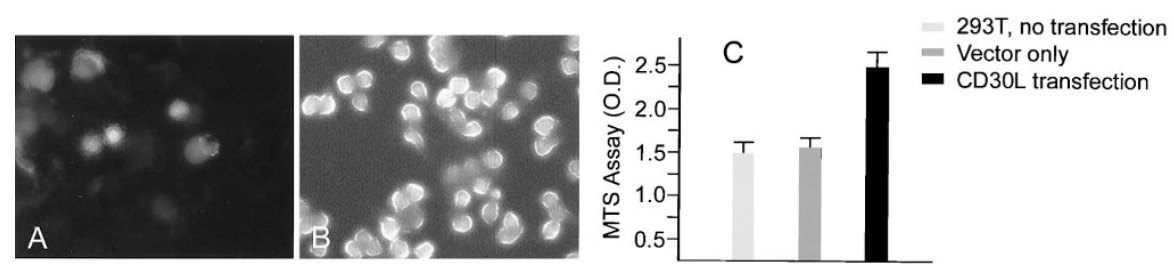

\section{Figure 1.}

The human CD30L/GFP expression vector was transfected into 293T cells with efficiency approximately $70-80 \%$ (B). Control, untransfected cells were photographed in A. Coculture of H-RS cells (eg, L428 cells) with CD30L-transfected 293T cells resulted in an increased cell proliferation, assayed by a colorimetric non-radioactive MTS/PMS assay. Increase in OD by $60 \%$ was noted in cocultures with CD30L ${ }^{+} 293 \mathrm{~T}$ cells, but not with control $293 \mathrm{~T}$ cells or vector-transfected $293 \mathrm{~T}$ cells. Results shown are representative of three independent experiments. Light gray bars: Test cells without co-culture with 293T cells. Gray bars: Test cells treated with vector-transformed $293 \mathrm{~T}$ cells. Black bars: Test cells cocultured with $\mathrm{CD} 0 \mathrm{~L}^{+} 293 \mathrm{~T}$ cells. 

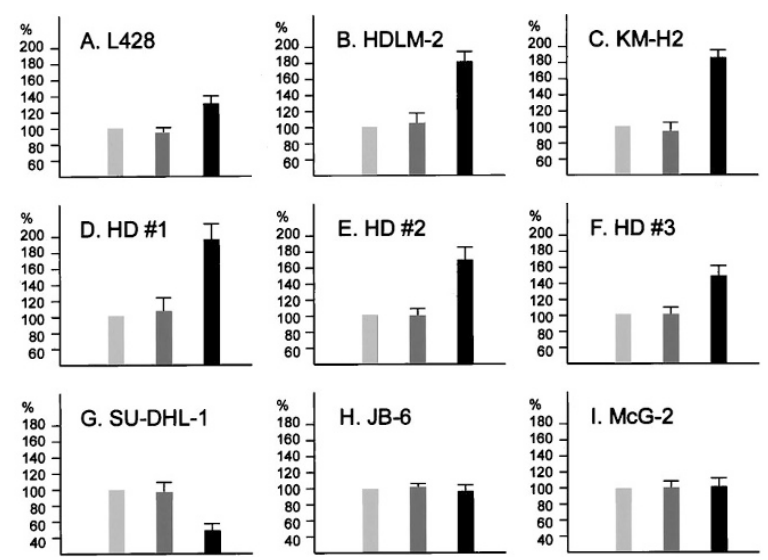

Figure 2.

Biological activity of $\mathrm{H}-\mathrm{RS}$ cells (A-F) and ALCL cells (G-I) was assessed by co-culture of $\mathrm{H}-\mathrm{RS}$ or $\mathrm{ALCL}$ cells with $\mathrm{CD}^{-} \mathrm{L}^{+}$COS-7 cells. The cells used were (A) L428, (B) HDLM-2, (C) KM-H2, (D-F) H-RS cells from three cases of $\mathrm{HD}$ (primary cultures, HD \#1, \#2, and \#3), (G) SU-DHL-1, (H) JB-6, and (I) McG-2. Increased thymidine uptake by $32 \%, 80 \%$, and $86 \%$ was observed in L428, HDLM-2, and KM-H2 cells, respectively. A significant increase in thymidine uptake was also noted in HD \#1 (by 100\%), HD \#2 (by 70\%), and $\mathrm{HD} \# 3$ (by $52 \%$ ). Decreased thymidine uptake by $54 \%$ was observed in SU-DHL-1 cells, but not in other ALCL cells including JB-6, McG-2, as well as PB-1 and two cases of ALCL (not shown). Control experiments were performed by replacement of $\mathrm{CD}^{2} \mathrm{~L}^{+}$cells with vector-transformed COS-7 cells. Results shown are representative of three independent experiments. Light gray bars: Test cells without co-culture with COS-7 cells. Gray bars: Test cells treated with vector-transformed COS-7 cells. Black bars: Test cells cocultured with $\mathrm{CD}_{0} 0 \mathrm{~L}^{+}$COS-7 cells.

cultures. A 45-60\% reduction in thymidine uptake was observed in CD30L- or anti-CD30 (HeFi-1)treated cultures as compared with the uptake in untreated, or Ber-H2-treated, or vector-transformed cell-treated (control) SU-DHL-1 cultures. In all tests, the numbers of cells and their viabilities remained very similar in both control and CD30L-treated cultures during the first 2 days of culture. Prolonged treatment (up to 2-3 days) of SU-DHL-1 cells with anti-CD30 $(\mathrm{HeFi}-1)$ resulted in a $25-30 \%$ reduction in the number of cells and an increased number of apoptotic cells.

\section{Expression of CD30L in Cultured Cells}

PCR amplification was used for detection of the presence of CD30L mRNA in cultured cells (Table 1). A major amplification product of $700 \mathrm{bp}$ was detected in H9, HUT78, and MT-2 (the latter two are HTLV-1positive) and in PHA-activated human PBL (containing activated $T$ cells). This suggests a possible autocrine role of CD30-CD30L in these cells. The specificity of these PCR products was confirmed by DNA sequence analysis. An additional CD30-/HTLV-1-positive T-cell line (HUT102) was CD30L-negative. None of the H-RS and ALCL cell lines was positive for CD30L. We also found that PHA-activated normal $T$ cells can express CD30 and/or CD30L. We were able to detect CD30 expression in approximately $20-25 \%$ of $\mathrm{PHA}$ activated $T$ cells by using immunofluorescence and flow cytometry.
Table 1. Expression of CD30 and CD3OL in Cultured Cells

\begin{tabular}{lcc}
\hline & CD30 & CD30L \\
\hline $\begin{array}{l}\text { Nonlymphoblastic T-cell lines } \\
\text { HUT78 }\end{array}$ & - & + \\
H9 & - & + \\
HUT102 & + & - \\
MT2 & + & + \\
ALCL cell lines & & \\
SU-DHL-1 & + & - \\
Mcg-2 & + & - \\
PB-1 & + & - \\
JB-6 & + & - \\
H-RS cell lines & & \\
HDLM-1 & + & - \\
L428 & + & - \\
KM-H2 & + & - \\
Normal T cells, PHA-activated & & \\
& $+(15 \%)$ & + \\
\hline
\end{tabular}

\section{Expression of CD3OL in Cultured Cells and in H-RS/ALCL Cells in Tissue Sections}

In all tissue sections, the anti-CD30L antibody reacted with a portion of the $\mathrm{H}-\mathrm{RS}$ cells (ranging from 50 $70 \%$ ) with diffuse cytoplasmic staining (Fig. 3, A and B). Membranous staining was not detected, as was also reported by Gruss et al (1996). The monoclonal anti-CD30L antibody was used in frozen sections of five cases of HD, and the resulting staining patterns were similar to those obtained from the polyclonal anti-CD30L in paraffin sections of the respective cases. Diffuse, weak cytoplasmic staining was also seen in the majority of histiocytes. Very weak cytoplasmic staining was detected in scattered lymphocytes. Most H-RS cells were CD30-positive, indicating co-expression of CD30 and CD30L in the majority of $\mathrm{H}-\mathrm{RS}$ cells.

In 10 of the 16 cases, most ALCL cells were CD30L-negative (Fig. 3, C and D). In four cases, weak and scattered cytoplasmic staining was seen in less than $5 \%$ of tumor cells. In the remaining two cases, cytoplasmic staining was observed in approximately $50-75 \%$ of lymphoma cells (Fig. 3, E and F). In all tissue sections, the anti-CD30L antibody reacted with a number of histiocytes and granulocytes (ranging from $30-60 \%$ ) with diffuse cytoplasmic staining (Fig. 3 , C to F). Membranous staining was not detected. Very weak cytoplasmic staining was also detected in scattered lymphocytes. The staining obtained with anti-CD30L is specific because it could be inhibited by preabsorption of antibodies with synthetic CD30L polypeptides.

\section{Discussion}

The present study showed that the anti-CD30L antibody reacted with the cytoplasm of a subpopulation (up to $70 \%$ ) of $\mathrm{H}-\mathrm{RS}$ cells and histiocytes in tissue sections from patients with HD (Fig. 1). The reaction 

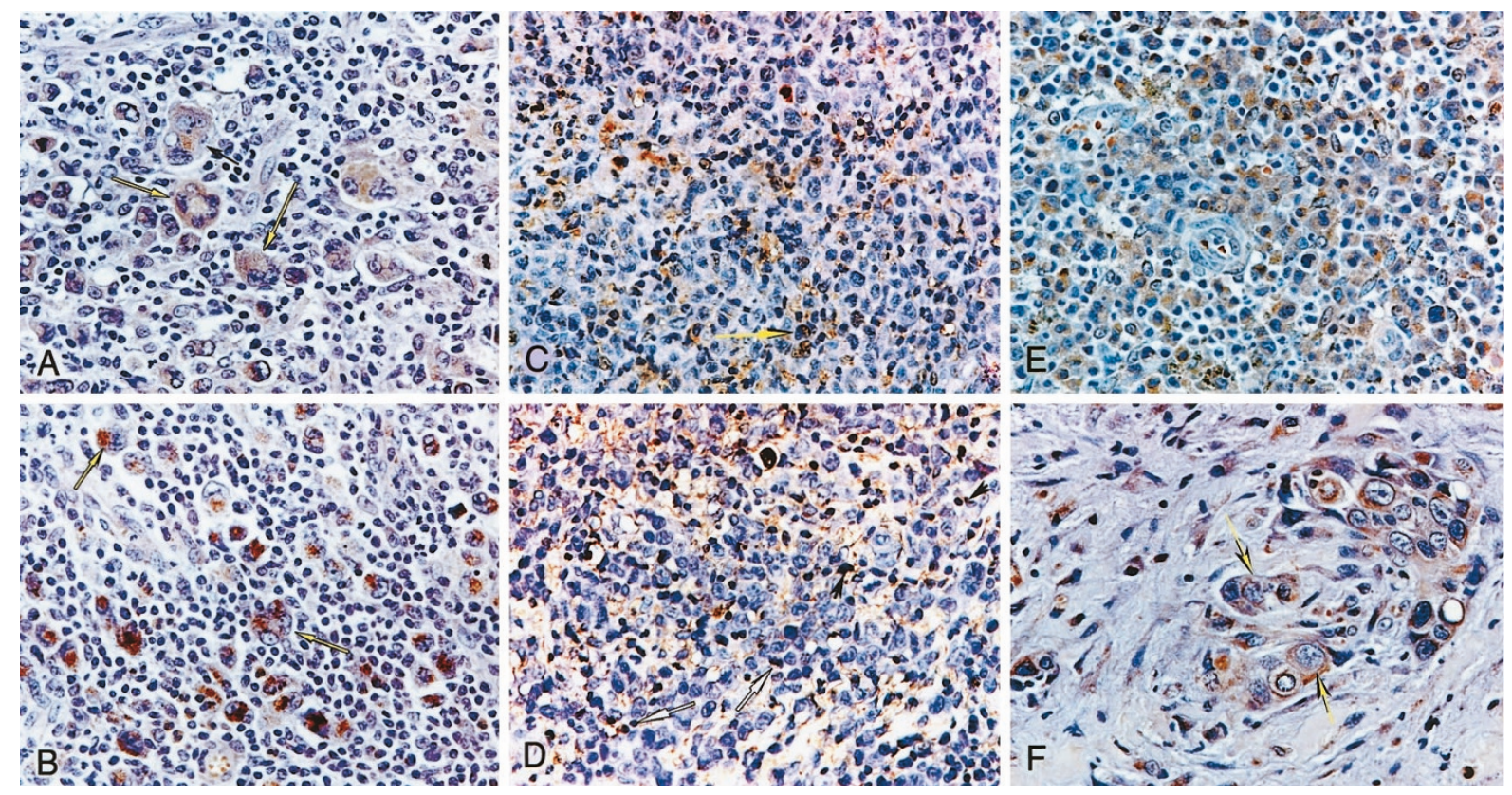

\section{Figure 3.}

Expression of CD30L in H-RS cells (A, B). Diffuse cytoplasmic staining was detected in the majority of H-RS cells. Scattered histiocytes and granulocytes were also weakly positive for anti-CD30L staining. The staining in scattered lymphocytes was very weak and was masked after counterstaining with hematoxylin. The great majority of ALCL cells were negative for anti-CD30L staining, as shown in (C) and (D). Arrow in C shows that rare ALCL cells may be CD30L-positive. Most stained cells in $C$ and $D$ were histiocytes or granulocytes. However, in two patients ( $E$ and $F$; both were of null cell phenotype), diffuse cytoplasmic staining was detected in ALCL cells.

with scattered $T$ cells is often weak and is barely detectable after counterstaining. This suggests a rather rich and/or stable source of CD3OL from H-RS cells as compared with $T$ cells. The presence of CD30L in CD30-positive H-RS cells in tissues strongly implies an autocrine regulatory role in the survival and/or proliferation of $\mathrm{H}-\mathrm{RS}$ cells. Although CD3OL can be detected in many activated cells, its expression in cultured long-term cell lines is limited to a few Burkitt's lymphoma cell lines (Gruss et al, 1994b). Loss of CD30L in cultured H-RS cells, and other CD30positive cultured cells as well, may indicate a loss of regulatory dependence in the CD30L-CD30 pathway for these cells.

An auto-regulatory function involving CD30L-CD30 is, however, infrequent in ALCL. Virtually all ALCL cells in long-term culture and the tumor cells in most patients with ALCL did not express CD30L. Expression of CD30L was detected only in two patients among 16 cases examined. The two patients had a rather aggressive clinical course.

The interaction of exogenous CD3OL and membrane-bound CD30 has been shown to induce pleiotropic effects on cells, resulting in proliferation, differentiation, or death. Activation-induced death of thymocytes after CD3 cross-linking is impaired in CD30-deficient mice (Amakawa et al, 1996). The CD30L-CD30 interaction, like TNF-R and CD95, is likely to be involved in cell death signaling and participates in negative selection of thymic $\mathrm{T}$ lymphocytes. In contrast, both CD30 and CD30L can be expressed by activated T cells, and the CD30-mediated signaling enhances proliferation and cytokine secretion by Th2 cells, and probably by Th1 and Th0 cells (Del Prete et al, 1995; Hamann et al, 1996; Mingari et al, 1996). For $\mathrm{B}$ cells, CD30L can stimulate its proliferation, antibody production, and secretion in a cytokine (eg, IL-4 and IL-5)-dependent manner (Shanebeck et al, 1995). Resting and activated $\mathrm{B}$ cells express CD30L, and a portion of activated B cells could express CD30 (Trentin et al, 1997; Younes et al, 1996).

Because H-RS cells, and frequently ALCL cells as well, are often in contact with surrounding reactive $T$ lymphocytes and histiocytes, the growth of lymphoma cells may constantly be modulated by the neighboring CD30L-positive cells. Virtually all H-RS cells either obtained from long-term cultures or isolated directly from patient specimens responded to exogenous $\mathrm{CD} 30 \mathrm{~L}$ to proliferate to various degrees, indicating an important role of the CD30L-CD30 interaction in growth regulation of H-RS cells. Hence, the CD30CD30L interaction may play a role in initiating and maintaining the neoplastic process by mediating H-RS-T, H-RS-B, and H-RS-eosinophilic contact (Pinto et al, 1996; Trentin et al, 1997).

For ALCL, CD30L may exert a paracrine inhibitory activity on cells of selected ALCL cell lines (ie, SUDHL-1 and Karpas 299) (Gruss et al, 1994a). The two cell lines (SU-DHL-1 and Karpas 299) (Epstein et al, 1978; Fischer et al, 1988) were derived from patients in advanced stages of ALCL, and yet their growth could still be inhibited by exogenous CD30L. This suggests that a CD30L-mediated inhibition exists not only during the early phase, but also during the late stages of the disease. The clinical course of ALCL is often aggressive (ie, in adults without cutaneous involve- 
ment), and the clinical outcome is similar to that of aggressive NHLs (Longo et al, 1995). However, ALCLs occurring in children or confined to the skin seem to run a more favorable course (Kadin et al, 1986; Pileri et al, 1994). These CD30-positive cutaneous T-cell lymphomas (CTCLs) comprise slowly progressive lymphoproliferative disorders [eg, lymphomatosis papulosis (LP)] with various types of evolution, ranging from spontaneous regression to systemic dissemination (Kadin et al, 1986; Pileri et al, 1994; Vecchi et al, 1993). A CD30L expression in CD30-positive neoplastic large cells might have a major role in the mechanism of self-regression of these CD30-positive CTCLs (Mori et al, 1999).

However, the effectiveness of this inhibition in inducing cytotoxicity, cell death, or growth inhibition in many other patients with ALCL may be questioned because an increase in apoptotic lymphoma cells is not a prominent feature in most, if not all, patients, and also because abundant CD30L-positive histiocytes or granulocytes are present in patients without the benefit of tumor regression. Several possibilities may explain how the ALCL cells escape inhibition by exogenous CD30L. First, sCD30 released from the tumor cells (Gause et al, 1991; Josimovic-Alasevic et al, 1989) may compete with membrane-bound CD30 for exogenous CD30L, thus minimizing the effect of exogenous CD30L. Second, the ALCL cells gain growth potential by the expression of growth-promoting molecules (eg, cytokines, cytokine receptors, oncogenes, etc.) and/or by deactivation of tumor suppressor genes. The growth signal delivered could well overcome the inhibitory signal derived from the CD30LCD30 pathway. Third, the ALCL cells, despite the persistent expression of CD30, may simply become resistant to exogenous CD30L, as we have observed in selected ALCL cell lines.

Whether CD30L expression in ALCL cells as well as the pattern of response by tumor cells to CD30L can be included in the list of prognostic factors for ALCL is a subject of future interest. The prognosis for CD30positive cutaneous CTCLs may become unfavorable, especially when skin lesions are disseminated, and relapse with systemic involvement may follow an initial spontaneous regression (Kadin et al, 1986; Pileri et al, 1994; Vecchi et al, 1993). Factors such as the presence of $t(2 ; 5)$ or p80 in tumor cells and the clonality of the tumor are being studied as prognostic indicators for the progression of the disease. However, a clonal rearrangement of the T-cell receptor (eg, TcR- $\gamma$ ) does not predict the subsequent development of systemic lymphoma (El-Azhary et al, 1994; Mac Grogan et al, 1996; Sugimoto et al, 1988; Whittaker et al, 1991). Furthermore, the $\mathrm{t}(2 ; 5)$ may identify a subset of CTCLs with common cytogenetic features, but the prognostic value of $\mathrm{t}(2 ; 5)$ and $\mathrm{p} 80$ expression and its associated factors, such as age, immunophenotype, skin involvement, and stage of the disease, may have to be re-evaluated as the methods of detection become more sensitive (Beylot-Barry et al, 1996; Shiota et al, 1994,1995). Future evaluation may also include the expression of CD30L in CTCLs cells (Mori et al, 1999).
The effects of CD30L on short-term cultured H-RS or ALCL cells, other than growth regulation, have not yet been studied systematically. In long-term cultures, the binding of CD30L (and of CD40L as well) to H-RS cells has been shown to affect the expression of cytokines (eg, IL-6, TNF, and lymphotoxin- $\alpha$ ) and adhesion/costimulatory molecules (CD54, CD80, and CD86) (Gruss et al, 1994c,1995; Pinto et al, 1996). In a large granular lymphoma cell line, YT, anti-CD30, which behaves like CD30L, has been shown to downregulate CD28 and CD45 expression and to upregulate the expression of CD25 (Bowen et al, 1993). The $\mathrm{H}-\mathrm{RS}$ cells both in tissue and in culture are usually $\mathrm{CD} 5^{+} / \mathrm{CD} 28^{-} / \mathrm{CD} 45^{-} / \mathrm{CD} 54^{+} / \mathrm{CD} 0^{+} / \mathrm{CD} 6^{+}$(Hsu and Hsu, 1994, 1995). The effects of CD30L on cultured ALCL cells, other than growth inhibition, have yet to be studied. In our study, no significant changes in the phenotypic expression by SU-DHL-1 cells nor by the other three ALCL cell lines have been observed.

In summary, the molecular pathogeneses of HD and ALCL seem to be distinct, despite the numerous cytomorphologic and immunophenotypic parallels that document the close relationship between these diseases. Thus far, our study seems to suggest a distinct CD30L function on $\mathrm{H}-\mathrm{RS}$ cells (proliferation) and ALCL cells (inhibition). However, it remains a possibility that in a small subset of patients, CD30L exerts an autocrine (self) and/or paracrine regulatory proliferative or survival function rather than an inhibitory function on ALCL cells. It has been speculated that in ALCLs, especially those with $t(2 ; 5)$, the activation of ALK interferes at a pivotal point with the intracellular signal transduction pathway, generating an activated CD30-positive phenotype (Wendtner et al, 1995). In this regard, CD30 expression may be secondary, and paracrine stimulatory effects such as CD30L-CD30 interaction may not be required for cell growth (Wendtner et al, 1995). However, in HD, and perhaps in a rare form of ALCL, autocrine and paracrine mechanisms between CD30L and CD30 seem to be relevant to maintaining tumor cells in an activated state. The phenomenon of paradoxical enhancement of proliferation versus induction of apoptosis is known to be associated with molecules in the TNF/TNF-R family. The exact mechanism is not known (reviewed in Ashkenazi and Dixit, 1998; Lenardo et al, 1999). The signaling of these molecules may be affected by their variable temporal/spatial expression in vivo. The CD30L-dependent proliferation of $\mathrm{H}-\mathrm{RS}$ cells may be mediated via the Ras/Raf-1/MAPK (ERKII) pathway (Wendtner et al, 1995). Further studies, however, are required for elucidation of the signal transduction pathway for the CD30Linduced cytotoxicity in ALCL cells and of the molecular and cellular events responsible for the regression or slow evolution of a subset of ALCLs.

\section{Materials and Methods}

\section{Antibodies, Sources, and Specificities}

A polyclonal anti-CD30L antibody was prepared by immunization of goats with synthetic peptide corresponding to amino acids 2-19 mapping to the amino 
terminus of CD30L (Santa Cruz Biotechnology, Houston, Texas). A monoclonal anti-CD30L antibody was obtained from Genzyme (Cambridge, Massachusetts). The antibody was prepared by immunization of mice with human CD30L-Fc type II, expressed in CV-1/CHO cells.

Two anti-CD30 antibodies were used for phenotyping and functional assay. The monoclonal antibody $\mathrm{HeFi}-1$ is known to react with the ligand-binding site and can be used as a CD30L-like reagent (Hecht et al, 1985; Tian et al, 1995). The antibody was kindly provided by Dr. R. Fisher (Harvard University, Boston). Another anti-CD30 antibody (Ber-H2), which recognizes a determinant not involved in ligand binding, was used as a control antibody in the functional assay (Younes et al, 1996).

\section{pBK-CMV-CD30L Construct and Preparation of CD30L- and 293T-Expressing COS-7 Cells}

COS-7 and 293T cells were used for the eukaryocytic production of CD30L. We used the human full-length CD30L cDNA (pBK-CMV-CD30L plasmid) to transform subconfluent COS-7 cells with the polycationic liposome reagent LipofectAMINE ä (Gibco/BRL). Eight hours later, the cells were trypsinized and reseeded in six-well cluster plates. The cells were grown in culture for 24-72 hours to permit transient expression of the inserted sequence. These cells were fixed with $1 \%$ paraformaldehyde for 5 minutes at $25^{\circ} \mathrm{C}$ and thoroughly washed before use. As control, COS-7 cells transfected with vector alone ( $\mathrm{pBK}-\mathrm{CMV})$ were used for verification of the specificity of CD30L activity expressed by CD30L-positive COS-7 cells.

In addition, we used the full-length coding region of CD30L as a template and inserted into the pEGFP-N1 expression vector (CLONTECH) (Chalfie et al, 1994). This human CD30L/GFP expression vector was then transfected into 293T cells using the lipofectamine reagent according to the manufacturer's instructions (3 $\mu \mathrm{g}$ of DNA/3 $\times 10^{5}$ cells). The $293 \mathrm{~T}$ cells were selected for their high transfection efficacy. The cells were grown in culture for 48 hours to permit transient expression of the inserted sequence. These cells were fixed with $1 \%$ paraformaldehyde for 5 minutes at $25^{\circ} \mathrm{C}$ and thoroughly washed before use. As control, 293T cells or 293T cells transfected with vector alone were used for verification of the specificity of CD30L activity expressed by CD30L-positive 293T cells. For the microscopic analysis of transfection efficacy, the cells were grown on glass coverslips and observed using a Nikon fluorescence microscope with epifluorescence illumination. GFP fluorescence was detected with a Nikon DM510 filter with illumination at $365 \mathrm{~nm}$ and long-bandpass emission.

\section{Cell Lines and Cultures}

Cells of cell lines including HDLM-1, L428, KM-H2 (these three were HD-derived), SU-DHL-1, PB-1, McG-2, JB6 (these four were ALCL cell lines), and H9, HUT78, HUT102, and MT2 (HTLV-I-positive lines) were cultured in RPMI 1640 medium as previously described (Hsu and Hsu, 1986). The ALCL cell lines (except SU-DHL-1) were kindly provided by Dr. M. Kadin (Harvard University). The nature and phenotypes of these cells have been reported previously (Wasik et al, 1994).

Both COS-7 and 293T cells were obtained from ATCC (Rockville, Maryland). The 293T cell line was cells from human embryonal kidney transformed by adenovirus DNA (ATCC CRL-1573). The COS-7 cells were cultured in RPMl1604 medium, and the 293T cells were cultured in opti DMEM medium (Gibco).

\section{Selection of HD and ALCL Tissues}

tk;2Tissue sections from 16 patients with ALCL and 21 patients with HD, including 13 nodular sclerosing, 7 mixed cellularity, and 1 lymphocyte-depletion type, were selected. The diagnosis of HD was confirmed by the characteristic histopathology of the involved lymph nodes and the characteristic cytologic features of $\mathrm{H}-\mathrm{RS}$ cells, which were $\mathrm{CD} 30^{+}$and $\mathrm{CD}^{-} / \mathrm{CD}^{-} \mathrm{O}^{-}$/ CD45-.

The diagnosis of CD30-positive ALCL was made based on the following criteria: (1) large anaplastic cells with abundant cytoplasm and large irregular nuclei as defined by the updated Kiel classification and the revised European-American lymphoma classification and (2) CD30 expression on nearly all of the neoplastic cells. The immunophenotypes of tumor cells were available in all 16 ALCL cases, 6 of which were of $\mathrm{T}$-cell origin $\left(\mathrm{CD} 45 \mathrm{RO}^{+}\right), 1$ of $\mathrm{B}$-cell origin $\left(\mathrm{CD} 20^{+}\right)$, and 9 of null-cell origin. The presence of $t(2 ; 5)$ was confirmed in seven patients by genetic translocation of the NPM gene on chromosome 5 by Southern blot analysis, RT-PCR, or cytogenetic analysis (Shiota et al, 1995).

Eleven of the 16 patients who met these criteria received combination chemotherapy as their initial treatment. Six patients were treated with 13-cis retinoic acid as primary or salvage treatment (Chou et al, 1996). The median duration of complete remission and of overall survival and the difference in survival among stages were not evaluated because of the short clinical follow-up period for our patients.

\section{Isolation of H-RS Cells or ALCL Cells from Patient Specimens}

$\mathrm{H}-\mathrm{RS}$ cells $\left(\mathrm{CD}_{15}{ }^{+} / \mathrm{CD}^{-} 5^{-} / \mathrm{CD} 45 \mathrm{RO}^{-} / \mathrm{EMA}^{-}\right)$were obtained from three surgical specimens, including two lymph nodes and a spleen, from three different patients. ALCL cells (CD15 $\left.{ }^{-} / \mathrm{CD}^{-} 0^{-} / \mathrm{CD} 4 \mathrm{RO}^{-}\right)$were obtained from two surgically resected lymph nodes from two different patients. These specimens were selected because of extensive involvement with the disease and because ample numbers of lymphoma cells were present; ie, H-RS cells $>15 \%$ and ALCL cells $>80 \%$. The sterile tumor tissues were minced and filtered through nylon mesh, and cells were collected by Ficoll-Hypaque gradient centrifugation. The pelleted cells (un-enriched samples) were resus- 
pended in RPMI 1640 medium containing 10\% fetal calf serum.

\section{Enrichment and Culture of H-RS Cells}

$\mathrm{H}-\mathrm{RS}$ cells were enriched after complement-mediated cytolysis of contaminating T cells, B cells, or monocytes. The effectiveness of $\mathrm{H}-\mathrm{RS}$ cell enrichment has been discussed in detail previously (Hsu et al, 1987). The cells were lysed by being subjected to two treatments with MAb cocktails containing anti-Leu 1 (CD5), -Leu 2a (CD8), -Leu 3a (CD4), -Leu M5 (CD11c), and anti-IgM, followed by fresh rabbit complement. These antibodies were purchased from Becton-Dickinson (San Jose, California). The lysed cells were removed on Ficoll-Hypaque gradients. The cells were recovered with viabilities of $85-95 \%$.

The presence of $\mathrm{H}-\mathrm{RS}$ cells in the enriched suspension was confirmed by positive staining with antiCD30. Contaminating T cells, B cells, and monocytes, which were present at less than 5\%, were detected by staining with anti-CD3, anti-CD20, and anti-CD11b. The enriched $\mathrm{H}$-RS cells were then cultured at 1 to $5 \times$ $10^{5} \mathrm{cells} / \mathrm{ml}$ in RPMl 1640 medium (Gibco) supplemented with $10 \%$ fetal calf serum, $2 \mathrm{~mm}$ glutamine, 50 mм 2-mercaptoethanol, and $10 \mu \mathrm{g} / \mathrm{ml}$ penicillin/streptomycin at $37^{\circ} \mathrm{C}$ in a humidified, $5 \% \mathrm{CO}_{2}$ atmosphere. The cultures could be maintained for up to 7 days. Cell viability ranged from $70-80 \%$.

\section{Effects of CD30L on Cultured H-RS or ALCL Cells}

To minimize binding between soluble CD30 and CD30L, we washed the cells thoroughly and added fresh culture medium before CD30L-expressing COS-7 or 293T cells, or anti-CD30 (HeFi-1, functions as CD30L) were added. Cells were cultured at $1 \times 10^{5}$ cells/ml on 96-well microplates (each well $200 \mu \mathrm{l}$ ). Anti-CD30 (HeFi-1 or Ber-H2) was added at a concentration of $10 \mu \mathrm{g} / \mathrm{ml}$. The CD30L-expressing cells were added to the culture in a 1:1 to 1:5 ratio (CD30Ltransfected cells:H-RS or ALCL cells) and maintained for 48 hours. The CD30L-induced proliferation or growth inhibition was evaluated from thymidine or BrdUrd uptake, a colorimetric nonradioactive MTS/ PMS assay, the number of cells in culture, and the viability of the cells.

For thymidine uptake, the cells were pulsed with 0.1 $\mu \mathrm{Ci} /$ well of $\left[{ }^{3} \mathrm{H}\right]$-thymidine $\left(\left[{ }^{3} \mathrm{H}\right]-\mathrm{TdR}, 25 \mathrm{Ci} / \mathrm{mmole}\right.$; Amersham, Arlington Heights, Illinois) for an additional 2 hours. The cells were harvested onto glass fiber filters, and the incorporated cpm (mean cpm $\pm \mathrm{SD}$ ) were assessed with a gamma counter (LKB Instruments Inc, Houston, Texas). All tests were performed in triplicate and were repeated three times. As control for the specificity of CD30L activity, we treated vectortransformed COS-7 cells or nonimmune mouse ascites at the same concentration.

For colorimetric nonradioactive MTS/PMS assay, the cells were cultured in the presence of $20 \mu$ of MTS (3-(4, 5-dimethylthiazol-2-yl)-5-(3-carboxymethoxyphenyl)-2-(4sulfophenyl)-2H-tetrazolium) and PMS (phenazine metho- sulphate) solution (Cell Titer96 Aqueous Non-radioactive Cell Proliferation Assay kit, Promega, Madison, Wisconsin) for 3 additional hours. The ODs were measured in an ELISA reader at a wavelength of $490 \mathrm{~nm}$.

For BrdUrd uptake, the cells were cultured in the presence of BrdUrd $\left(1 \times 10^{-6} \mathrm{M}\right)$ for 2 additional hours before they were harvested. The cells were washed with Tris-buffered saline $(0.1 \mathrm{M}, \mathrm{pH} 7.6)$, prepared as cytospin smears, and examined for uptake of BrdUrd by the nuclei.

\section{Production of CD30L by Cultured H-RS or ALCL Cells}

The expression of CD30L mRNA in long-term cultured CD30-positive cells was examined by RT-PCR. RNAs from cultured cells and from $\mathrm{PHA}$-activated normal $\mathrm{T}$ cells were prepared and reverse-transcribed into cDNA. Briefly, $12 \mu \mathrm{l}$ of total RNA (1-5 $\mu \mathrm{g})$ was mixed with $1 \mu \mathrm{l}$ of oligo-dT, heated to $70^{\circ} \mathrm{C}$ for 10 minutes, and then quick-chilled to $0^{\circ} \mathrm{C}$. Two microliters of $10 \times$ synthesis buffer $(200 \mathrm{~mm}$ Tris-HCl, $\mathrm{pH}$ 8.4; $500 \mathrm{~mm} \mathrm{KCl;} 25 \mathrm{~mm}$ $\left.\mathrm{MgCl}_{2} ; 1 \mathrm{mg} / \mathrm{ml} \mathrm{BSA}\right), 1 \mu \mathrm{l}$ of $10 \mathrm{~mm}$ dNTP mix, $2 \mu \mathrm{l}$ of $0.1 \mathrm{M}$ DTT, and $1 \mu \mathrm{l}$ of RNasin (20 U, Promega) were added with $1 \mu$ l of Super Script reverse transcriptase (200 U/ml, BRL, Life Technologies Inc, Gaithersburg, Maryland). The reaction mixture was incubated at $42^{\circ} \mathrm{C}$ for 60 minutes, then heated at $90^{\circ} \mathrm{C}$ for 5 minutes for inactivation of the enzyme. Finally, $1 \mu$ l of RNase $\mathrm{H}$ (2 $\mathrm{U} / \mathrm{ml}$ ) was added to the mixture, which was incubated at $37^{\circ} \mathrm{C}$ for 20 minutes.

For PCR, we prepared a reaction mixture containing $10 \times$ synthesis buffer, $8 \mu \mathrm{l}$; sterile double-distilled water, $68 \mu \mathrm{l} ; 10 \mathrm{~mm}$ amplification primers, $1 \mu \mathrm{l}$ each; and 2-5 U/I Taq DNA polymerase (BRL), $1 \mu \mathrm{l}$. Thirtyfive rounds of PCR were performed by cycling at $94^{\circ} \mathrm{C}$ for 20 seconds, $55^{\circ} \mathrm{C}$ for 20 seconds, and $72^{\circ} \mathrm{C}$ for 30 seconds in a programmable thermocycler (USA/Scientific Plastics, Ocala, Florida).

For visualization, a portion of the PCR mixture $(6 \mu \mathrm{l})$ was added to $1 \mu$ l of stop buffer (500 $\mu$ l glycerol, 200 $\mu \mathrm{l} 0.5$ M EDTA, $146 \mu \mathrm{l}$ 1\% bromophenol blue, $35 \mu \mathrm{l}$ $20 \%$ SDS, $150 \mu \mathrm{l} 1 \mathrm{M}$ Tris- $\mathrm{HCl}, \mathrm{pH} 7.8$, and $30 \mu \mathrm{l}$ distilled water), and electrophoresis was performed in a $75 \mathrm{~V}$ constant-voltage field in 3\% NuSieve GTG/1\% Sea Kem ME agarose. The specificities of the amplified products obtained with the CD30L primers were confirmed by sequencing.

The oligonucleotide primers for CD30L were prepared based on the published sequences $(10,18)$. The human $\beta$-actin primers (as controls) were $5^{\prime}$-CTCTTCCAGCCTTCCTTCCTG-3' (sense) and 5' -GAAGCATTTGCGGTGGACGAT-3' (antisense). These primers were synthesized by the solid-phase $\beta$-cyanoethyl phosphoramidite method on an automated DNA synthesizer (Cyclone Plus, MilliGen/Biosearch, Novato, California) and were purified by electrophoresis on polyacrylamide gels.

\section{Expression of CD3OL by H-RS Cells or ALCL in Tissue Sections}

An avidin-biotin-peroxidase complex method was used for detecting the expression of CD30L in 
formalin-fixed, paraffin-embedded tissue sections (Hsu et al, 1981). The antibody was added at $2 \mu \mathrm{g} / \mathrm{ml}$; this was followed by addition of biotin-labeled rabbit antigoat lg. After extensive washing, the sections were incubated with avidin-biotin-peroxidase complex and then developed in DAB- $\mathrm{H}_{2} \mathrm{O}_{2}$ solution. As control for the staining specificity, we omitted the primary antibody or used the preabsorbed antibody. Absorption was performed by incubation of anti-CD30L with the peptide that was used for generation of antibody. The sections were counterstained with hematoxylin, dehydrated, and cleared as in routine processing.

\section{References}

Amakawa R, Hakem A, Kundig TM, Matsuyama T, Simard JJ, Timms E, Wakeham A, Mittruecker HW, Griesser H, Takimoto $H$, Schmits R, Shahinian A, Ohashi P, Penninger JM, and Mak TW (1996). Impaired negative selection of T cells in Hodgkin's disease antigen CD30-deficient mice. Cell 84:551-562.

Ashkenazi A and Dixit VM (1998). Detah receptors: Signaling and modulation. Science 281:1305-1308.

Beylot-Barry M, Lamant L, Vergier B, de Muret A, Fratiag S, Delord B, Dubus P, Vaillant L, Delaunay M, Mac Grogan G, Beylot C, de Mascarel A, Delsol G, and Merlio JP (1996). Detection of $t(2 ; 5)(p 23 ; q 35)$ translocation by reverse transciptase polymerase chain reaction and in situ hybridization in CD30-positive primary cutaneous lymphoma and lymphomatoid papulosis. Am J Pathol 149:483-492.

Bowen MA, Olsen KJ, Cheng L, Avila D, and Podack ER (1993). Functional effects of CD30 on a large granular lymphoma cell line, YT. Inhibition of cytotoxicity, regulation of CD28 and IL-2R, and induction of homotypic aggregation. J Immunol 151:5896-5906.

Chalfie M, Tu Y, Euskirchen G, Ward WW, and Prasher DC (1994). Green fluorescent protein as a marker for gene expression. Science 263:802-805.

Chou WC, Su IJ, Tien HF, Liang DC, Wang CH, Chang YC, and Cheng AL (1996). Clinicopathologic, cytogenetic, and molecular studies of 13 Chinese patients with $\mathrm{Ki}-1$ anaplastic large cell lymphoma: Special emphasis on the tumor response to 13-cis retinoic acid. Cancer 78:1805-1812.

Del Prete G, De Carli M, D’Elios MM, Daniel KC, Almerigogna F, Alderson M, Smith CA, Thomas E, and Romagnani S (1995). CD30-mediated signaling promotes the development of human helper type 2-like T cells. J Exp Med 182:1655-1661.

Dürkop H, Latza U, Hummel M, Eitelbach F, Seed B, and Stein H (1992). Molecular cloning and expression of a new member of the nerve growth factor receptor family that is characteristic for Hodgkin's disease. Cell 68:421-427.

El-Azhary R, Gibson L, Kurtin P, Pittelkow M, and Muller S (1994). Lymphomatoid papulosis: A clinical and histopathological review of 53 cases with leukocyte immunophenotyping, DNA flow cytometry, and T-cell receptor gene rearrangement studies. J Am Acad Dermatol 30:210-218.

Epstein AL, Levy R, Kim H, Henle W, Henle G, and Kaplan HS (1978). Biology of the human malignant lymphomas IV. Functional characterization of ten diffuse histiocytic lymphoma cell lines. Cancer 42:2379-2391.

Fischer P, Nacheva E, Mason DY, Sherrington PD, Hoyle C, Hayhoe FGJ, and Karpas A (1988). A Ki-1 (CD30)-positive human cell line (Karpas 299) established from a high-grade non-Hodgkin's lymphoma, showing a 2;5 translocation and rearrangement of the T-cell receptor $\beta$-chain gene. Blood 72:234-240.

Gattei V, Degan M, Gloghini A, De luliis A, Improta S, Rossi FM, Aldinucci D, Perin V, Serraino D, Babare R, Zagonell V, Gruss HJ, Carbone A, and Pinto A (1997). CD30 ligand is frequently expressed in human hematopoietic malignancies of myeloid and lymphoid origin. Blood 89:2048-2059.

Gause A, Pohl C, Tschiersch A, Da Costa L, Jung W, Diehl V, Hasenclever D, and Pfreundschuh M (1991). Clinical significance of soluble CD30 antigen in the sera of patients with untreated Hodgkin's disease. Blood 77:1983-1988.

Gruss HJ and Herrmann F (1996). CD30 ligand, a member of the TNF ligand superfamily, with growth, and activation control for CD30+ lymphoid and lymphoma cells. Leuk Lymphoma 20:397-409.

Gruss HJ, Boiani N, Williams DE, Armitage RJ, Smith CA, and Goodwin RG. (1994a). Pleiotropic effects of the CD30 ligand on CD30-expressing cells and lymphoma cell lines. Blood 83:2045-2056.

Gruss HJ, DaSilva N, Hu Z-B, Uphoff CC, Goodwin RG, and Drexler HG. (1994b). Expression and regulation of CD30 ligand and CD30 in human leukemia-lymphoma cell lines. Leukemia 8:2083-2094.

Gruss HJ, Hirschstein D, Wright B, Ulrich D, Caligiuri MA, Barcos M, Strockbine L, Armitage RJ, and Dower SK. (1994c). Expression and function of CD40 on Hodgkin and Reed-Sternberg cells and the possible relevance for Hodgkin's disease. Blood 84:2305-2314.

Gruss HJ, Pinto A, Gloghini A, Wehnes E, Wright B, Boiani N, Aldinucci D, Gattei V, Zagonel V, Smith CA, Kadin ME, von Schilling C, Goodwin RG, Hermann F, and Carbone A (1996). CD30 ligand expression in nonmalignant and Hodgkin's disease-involved lymphoid tissues. Am J Pathol 149:469-481.

Gruss HJ, Ulrich D, Braddy S, Armitage RJ, and Dower SK (1995). Recombinant CD30 ligand and CD40 ligand share common biological activities on Hodgkin and ReedSternberg cells. Eur J Immunol 25:2083-2089.

Hamann D, Hikens CMU, Grogan JL, Lens SMA, Kapsenberg ML, Yazdanbakhsh M, van Lier RAW (1996). CD30 expression does not discriminate between human Th1- and Th2type T cells. J Immunol 156:1387-1391.

Hecht TT, Longo DL, Cossman J, Bolen JB, Hsu SM, Israel $\mathrm{M}$, and Fisher RI (1985). Production and characterization of a monoclonal antibody that binds Reed-Sternberg cells. J Immunol 134:4231-4236.

Hsu SM and Hsu PL (1986). Phenotypes and phorbol esterinduced differentiation of human histiocytic lymphoma cell lines (U-937 and SU-DHL-1) and Reed-Sternberg cells Am J Pathol 122:223-230.

Hsu SM and Hsu PL (1994). The nature of Reed-Sternberg cells - phenotype, genotype, and other properties. Crit Rev Oncogen 5:213-246.

Hsu SM and Hsu PL (1995). Phenotypic expression of Hodgkin's disease: Relationship to biologic, immunologic and functional properties of Reed-Sternberg cells. In Tumor Markers, eds, Garrett CT, and Sell S. pp 289-334.

Hsu SM, Ho YS, and Hsu PL (1987). The effect of monoclonal antibodies on the surface antigen on Reed-Sternberg cells. J Natl Cancer Inst 79:1091-1099. 
Hsu SM, Raine L, and Fanger H (1981). Use of avidin-biotinperoxidase complex $(A B C)$ in immunoperoxidase techniques: A comparison between $A B C$ and un-labeled antibody (PAP) procedures. J Histochem Cytochem 29:577-580.

Josimovic-Alasevic O, Dürkop H, Schwarting R, Backé E, Stein $\mathrm{H}$, and Diamantstein T (1989). Ki-1 (CD30) antigen is released by $\mathrm{Ki}-1$-positive tumor cells in vitro and in vivo. I. Partial characterization of soluble Ki-1 antigen and detection of the antigen in cell culture supernatants and in serum by an enzyme-linked immunosorbent assay. Eur J Immunol 19:157-162.

Kadin ME, Sako D, Berliner N, Franklin W, Woda B, Borowitz M, Ireland K, Schweid A, Herzog P, Lange B, and Dorfman R (1986). Childhood Ki-1 lymphoma presenting with skin lesions and peripheral lymphadenopathy. Blood 68:1042-1049.

Lenardo M, Chan FKM, Hornung F, McFarland H, Siegel R, Wang J, and Zheng L (1999). Mature $T$ lymphocyte apoptosis: Immune regulation in a dynamic and unpredictable antigenic environment. Annu Rev Immunol 17:221-253.

Longo G, Federico M, Pieresca C, Avanzini P, lannitto E, Di Prisco AU, Baldini L, Brugiatelli M, Clo V, Bevini M, and Silingardi V. (1995). Anaplastic large cell lymphoma (CD30+/ $\mathrm{Ki}-1+)$. Analysis of 35 cases followed at GISL centres. Eur J Cancer 31A:1763-1767.

Mac Grogan G, Vergier B, Dubus P, Beylot-Barry M, Delaunay MM, Eghbali H, Rivel J, Vital C, De Mascarel A, Bloch B, and Merlio JP (1996). CD30+ cutaneous lymphoma: A clinico-pathological and molecular study of 17 cases. Am J Clin Pathol 105:440-450.

Mingari MC, Maggi E, Camiaggi A, Annunziato F, Schiavetti F, Manetti R, Moretta L, and Romagnani S (1996). Development in vitro of human CD4+ thymocytes into functionally mature Th2 cells. Exogenous interleukin-12 is required for priming thymocytes to produce both Th1 cytokines and interleukin-10. Eur J Immunol 26:1083-1087.

Mori M, Manuelli C, Pimpinelli N, Navilia C, Maggi E, Santucci M, Bianchi B, Capuugi P, Giannotti B, Kadin ME (1999). CD30-CD30 ligand interaction in primary cutaneous CD30 (+) T-cell lymphomas: A clue to the pathophysiology of clinical regression. Blood 94:3077-3083.

Nicod LP and Isler P (1997). Alveolar macrophages in sarcoidosis coexpress high levels of CD86 (B7.2), CD40, and CD30L. Am J Resp Cell Mol Biol 17:91-96.

Pileri S, Bocchia M, Baroni CD, Martelli M, Falini B, Sabattini E, Gherlinzoni F, Amadori S, Poggi S, Mazza P, Burgio V, Zinzani PL, Melilli G, Benni M, Saragoni L, Martelli MF, Stein $H$, Mandelli E, and Tura S (1994). Anaplastic large cell lymphoma (CD30+/Ki-1+): Results of a prospective clinicopathological study of 69 cases. Br J Haematol 86:513-523.

Pinto A, Aldinucci D, Gloghini A, Zagonel V, Degan M, Improta S, Juzbasic S, Todesco M, Perin V, Gattei V, Herrmann F, Gruss HJ, and Carbone A (1996). Human eosinophils express functional CD30 ligand and stimulate proliferation of a Hodgkin's disease cell line. Blood 88:3299-3305.

Shanebeck KD, Maliszewski CR, Kennedy MK, Picha KS, Smith CA, Goodwin RG, and Grabstein KH (1995). Regulation of murine $B$ cell growth and differentiation by CD30 ligand. Eur J Immunol 25:2147-2153.

Shiota M, Fujimoto J, Takenaga M, Satoh H, Ichinohasama R, Abe M, Nakano M, Yamamoto T, and Mori S (1994). Diagnosis of $\mathrm{t}(2 ; 5)(\mathrm{p} 23 ; \mathrm{q} 35)$-associated $\mathrm{Ki}-1$ lymphoma with immunohistochemistry. Blood 84:3648-3652.
Shiota M, Nakamura S, Ichinohasama R, Abe M, Akagi T, Takeshita M, Mori N, Fujimoto J, Miyauchi J, Mikata A, Nanba K, Takami T, Yamabe H, Takano Y, Izumo T, Nagatani T, Mohri N, Nasu K, Satoh H, Katano H, Fujimoto J, Yamamoto T, and Mori S (1995). Anaplastic large cell lymphomas expressing the novel chimeric protein p80NPM/ALK: A distinct clinicopathologic entity. Blood 86:1954-1960.

Smith CA, Farrah T, and Goodwin RG (1994). The TNF receptor superfamily of cellular and viral proteins: activation, costimulation, and death. Cell 75:959-962.

Smith CA, Gruss HJ, Davis T, Anderson D, Farrah T, Baker E, Sutherland GR,, Brannan Cl, Copeland NG, Jenkins NA, Grabstein KH, Gliniak B, McAlister IB, Fanslow W, Alderson M, Falk B, Gimpel S, Gillis S, Din WS, Goodwin RG, and Armitage RJ (1993). CD30 antigen, a marker for Hodgkin's lymphoma, is a receptor whose ligand defines an emerging family of cytokines with homology to TNF. Cell 73:349-1360.

Sugimoto H, Nakayama F, Yamauchi T, Tokura Y, Iwatsuki K, Takigawa M, Yamada M, and Maeda M (1988). Ki-1+ cutaneous lymphoma: Gene rearrangement analysis of tumor cells in tissue and short-term culture of a patient. Arch Dermatol 124:405-408.

Tian ZG, Longo DL, Funakoshi S, Asai O, Frris DK, Widmer M, and Murphy WJ (1995). In vivo antitumor effects of unconjugated CD30 monoclonal antibodies on human anaplastic largecell lymphoma xenografts. Cancer Res 55:533-5341.

Trentin L, Zambello R, Sancetta R, Facco M, Cerutti A, Perin A, Siviero M, Basso U, Bortolin M, Adami F, Agostini C, Semenzato G (1997). B lymphocytes from patients with chronic lymphoproliferative disorders are equipped with different costimulatory molecules. Cancer Res 57:4940-4047.

Vecchi V, Burnelli R, Pileri S, Rosito P, Sabattini E, Civino A, Pericoli R, and Paolucci G (1993). Anaplastic large cell lymphoma $(\mathrm{Ki}-1+/ \mathrm{CD} 30+)$ in childhood. Medical Pediatric Oncol 21:402-410.

Wasik MA, Sioutos N, Tuttle M, Butmarc JR, Kaplan WD, and Kadin ME (1994). Constitutive secretion of soluble IL-2 receptor by a human T-cell lymphoma xenografted into SCID mice: Correlation of tumor volume with concentration of tumor-derived soluble IL-2R in body fluids of the host mice. Am J Pathol 144:1089-1097.

Wendtner CM, Schmitt B, Gruss HJ, Druker BJ, Emmerich B, Goodwin RG, and Hallek M (1995). CD30 ligand transduction involves activation of a tyrosine kinase and of mitogenactivated protein kinase in a Hodgkin's lymphoma cell line. Cancer Res 55:4157-4161.

Whittaker S, Smith N, Jones R, and Luzzatto L (1991). Analysis of $\alpha, \beta$, and $\gamma \mathrm{T}$-cell receptor genes in lymphomatoid papulosis: Cellular basis of two distinct histologic subsets. J Invest Dermatol 96:786-791.

Wiley SR, Goodwin RG, and Smith CA (1996). Reverse signaling via CD30 ligand. J Immunol 57:363-3639.

Younes A, Consoli U, Zhao S, Snell V, Thomas E, Gruss HJ, Cabanillas F, Andreeff M (1996). CD30 ligand is expressed on resting normal and malignant human $\mathrm{B}$ lymphocytes. $\mathrm{Br} \mathrm{J}$ Haematol 93:569-571. 